\title{
Features of the Internal Control of Foreign Trade Transactions
}

Plotnikova L.A.

Kazan Federal University, Institute of Management, Economics and Finance, Kazan, 420008, Russia

Email: Ipl.kazan@gmail.com

\section{Doi:10.5901/mjss.2015.v6n1s3p379}

\section{Abstract}

The article describes the requirements of the legislation in the field of implementation of internal control system on the enterprises, a necessity and an importance of control, explores the possibilities and features of the organization of the internal control of the foreign trade transactions, analyzes all possible risks (financial, legal, market, credit, geographic) arising in foreign trade activity. The author reveals the possible methods, techniques and procedures to exercise the internal control. Besides there is documentation's aspect under the internal control of foreign trade operations in the article.

Keywords: internal control system, foreign trade transactions, financial risk, legal risk, market risk, loan and credit risk, foreign currency, foreign economic activity.

\section{Introduction}

Recently there were quite a lot of changes in the legislation of the Russian Federation in the field of accounting and reporting. So, the requirement to organize the internal control system in the companies for their activities is one of the innovations adopted by the State Duma of the Russian law dated 06.12.2011, \# 402-FZ "On Accounting". The internal control should be organized in the context of the activity lines, which are presented in image 1.

There are some clarifications of the image's data below:

a. commercial organizations listed in Article 5 of the Federal Law dated 30.12.2008 \# 307-FZ "On Auditing" and some non-profit organizations carrying out their activities in accordance to other laws, are the subjects of mandatory audit;

b. directors of small and medium-sized businesses and non-profit organizations, which apply simplified accounting methods, have the right to take accounting to himself personally in accordance to the paragraph 3 of Article 7 of the Federal Law dated 06.12.2011 \# 402-FZ "On Accounting".

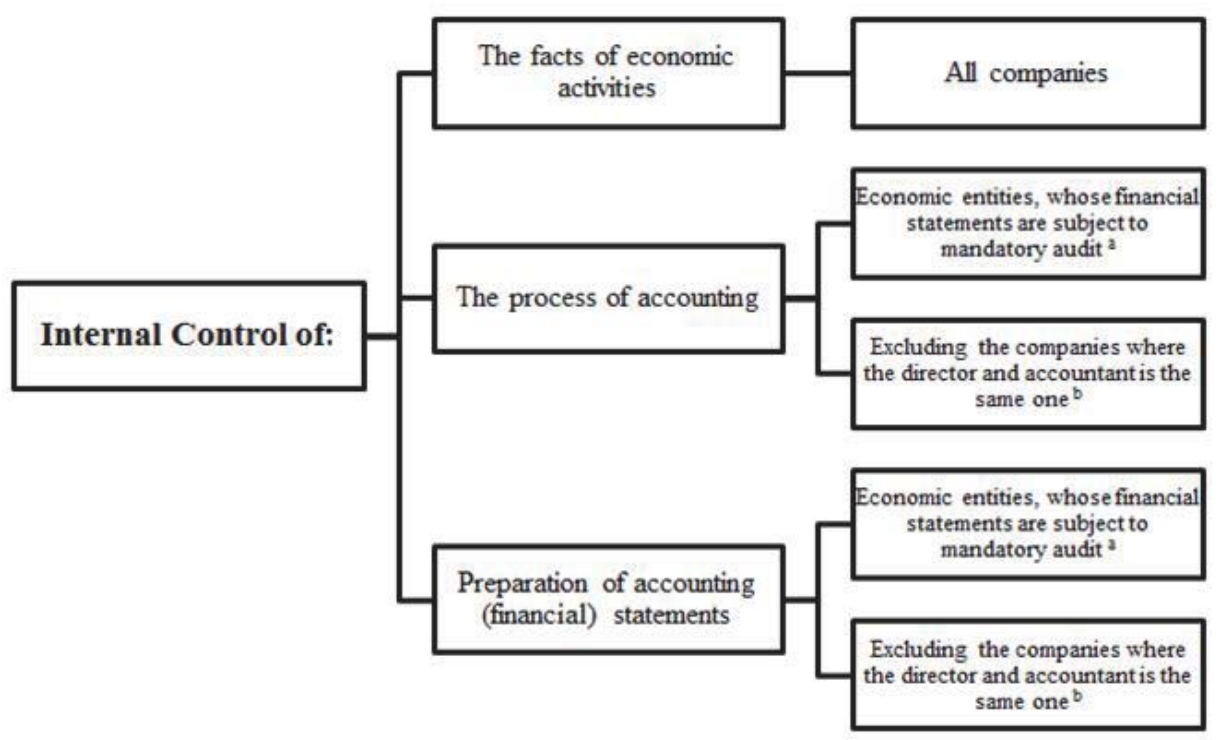

Image 1. Areas of Internal Control 
Thus, the object of internal control are not just accounting and reporting, but the facts of economic activities, they are: any activity's operations, transactions and events, affecting the financial condition of the company, its financial performance and (or) cash flows.

\section{Progress to Date: The Russian Experience}

It should be noted that the legislation of the Russian Federation did not set any restrictions on the rules, methods and procedures for this internal control. However, in accordance to the Order of the RF Ministry of Finance dated 30.11.2011 \# 440 the "Plan of the Ministry of Finance of Russia in 2012 - 2015 on the development of accounting and reporting in the Russian Federation on the basis of International Financial Reporting Standards" was approved. So, in 2014 to be developed recommendations for companies on the organization and implementation of the internal control of accounting and preparation of financial statements in accordance with paragraph 16 of this Plan in order to improve the quality and accessibility of information formed in the accounting and reporting.

Internal control should be considered as an important component of management in the company [1]. In the same time the very system of internal control can and should include several important elements, which are shown in image 2.

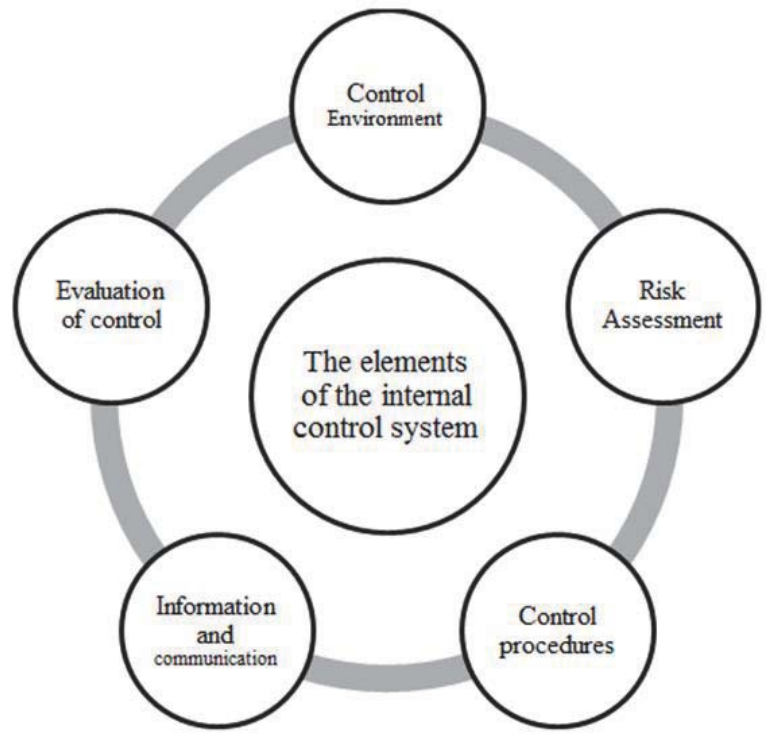

Image 2. The main elements of the internal control system

As the image shows the internal control system can consist of five main elements that have an intrinsic link between. For example, it is impossible to compile a complete list of procedures for monitoring more fully without the search and evaluation of all possible risks. Or, for another example, it is impossible to calculate, to estimate the parameters under control and make reasoned conclusions on the results of monitoring without the presence of a sufficiently complete and comprehensive information base [2].

Currently, in our country there are big changes in the economy [3]. Russia's membership in the World Trade Organization has the greatest influence on this fact. Now many Russian companies involved in foreign trade interact with non-residents of the country very closely [4]. A circle of users of financial statements of Russian companies is much wider [5]. Consequently, one of the priorities of heads of these companies is to ensure the preparation of reliable reporting and disclosure of information useful to users in it [6].

We believe that in this context, risk assessment and their identification and management have to become the one of the key elements of internal control. Information about the risks of business is need to fully understand the financial position, results of its activity and changes in its financial position [7]. Company is exposed to various internal and external factors: industrial, legal and other significant conditions, events, circumstances and actions during its foreign trade activities. So, there are a lot of different business risks on the practice, some of which are presented in the image 3. 


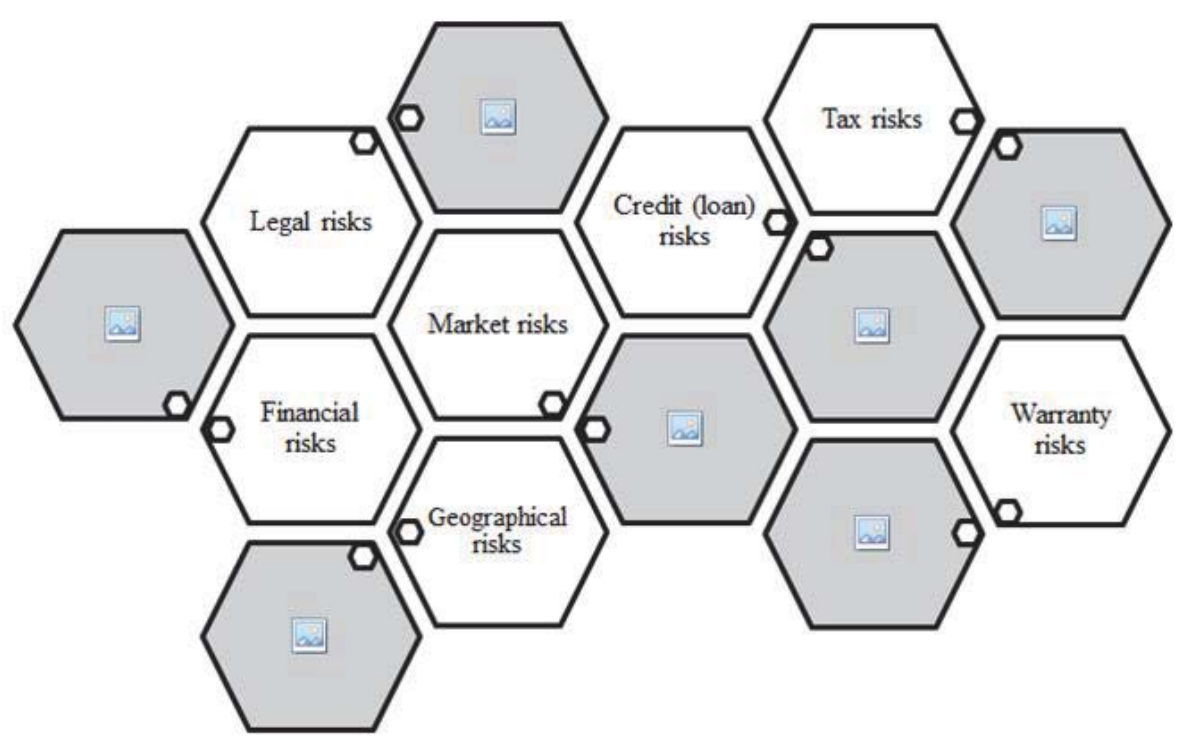

Image 3. Possible risks of economic activity of company

If the company is engaged in foreign trade, the assessment of market risks is very important. Market risks arise from adverse effects of a sharp change in market parameters [8], in particular, is not so much the prices of goods as foreign exchange rates. Moreover, changes in foreign currency exchange rates are not dependent on the company, and an external factor. Evaluation of credit (loan) risks is also important in the event that the company has the dubious contractors and questionable partners. Even despite the fact that in accordance with the legislation of foreign economic activity the director of company must be sure that the principle of repatriation will be executed. So, the payment for export goods will be received in time or imported goods go to Russia in time if the prepayment was made earlier.

Director of company should pay attention to the legal risks at the organization of control of foreign trade transactions. They may be associated with changes in foreign economic activity rules, handling currency, customs and tax laws. All of these affect to value of financial result of operations, resulting in the implementation of foreign trade transactions. Geographical risks are also very important: the interstate and regional risks. Their level largely depends on the political and economic situation of the country in which the Russian company conducts its foreign trade activity.

In our opinion information about key business risks should be disclosed in the financial statements.

The process of the organization and implementation of internal control involves a lot of different procedures. These procedures are aimed at minimizing the risks and thus allow achieving the purpose of the foreign trade activity [9]. If we consider the procedure "documenting" in relation to the internal control of export and import operations in more detail, we can suggest the following. For example, residents of the country are required to prepare the documents: an official message about foreign currency transactions and passport of foreign trade transaction. These documents are documents of foreign trade transactions control and have to be represented to authorized bank of company. Why not use them for the control of foreign trade transactions? It is quite possible, and we recommend you do so. At the same time these two control documents could be viewed as working documents for the implementation of the procedure "documenting". According to the requirements of legislation in the sphere of foreign trade activity the document «passport of foreign trade transaction» has to be formed only on contracts whose value exceeds the equivalent of USD 50,000. However, company's manager may decide that the transaction passport must be formed on any foreign trade agreement, regardless of its value. This decision will allow the company's management for internal control regularly and continuous method.

It should be noted that one of the important tasks of accounting is quality information. It is necessary to submit high quality information in time in order to achieve effective functioning of the company's internal control system. Regular monitoring of the performance of the company, including the analysis of individual trade transactions, is a type of assessment of internal control. It allows management to develop the most effective methods and means for the function of internal controls.

Manager can create a separate service deliberately or seek the assistance of external consultants, including audit firms, for the implementation and organization of the internal control's system. In any case, it must be remembered about 
the observing the principle of rationality [10], that is: all the costs of establishing and implementing a system of internal control in the company should be justified and economically feasible [11]. For example, the director of a small business may impose obligations on the controller himself personally in the event that the number of personnel cannot delimit the powers, or reduce the use of the full range of internal control procedures and to pay more attention to those areas of the company, which has the highest risk [12].

\section{Unsolved Problems}

The process of introducing the company's internal control system must be documented. Unfortunately or fortunately, this question is not quite regulated by the state. In this regard, the head of the economic entity is free to choose and has the ability to set their own rules of documenting [13]. In our opinion, the head of the company has two ways to solve this problem. First way is a following: the special Regulation on the Internal Control System may be formed in the company. The second (alternative) method is: the control functions of personnel may be registered in other working papers, for example in the Policy of accounting, the Regulation on the accounting service or other departments, the List of job descriptions, Collective agreement, Company strategy, the Code of corporate and professional Ethics and other documents.

In this matter, the use of professional judgment of various experts manifested more fully. This again allows you to confirm the fact that reform of accounting and reporting in the Russian Federation is aimed at convergence with International Accounting Standards primarily. And such reform involves not only the harmonization, but also the convergence of accounting systems, which undoubtedly affects the higher quality of information collected in accounting $[14,15]$. For example, if harmonization is only the approximation of different accounting systems, that is, involves the application along with the local regulations and international standards, the convergence has a penetrating character. Convergence implies full implementation of new (international) accounting rules in our reality and the complete replacement of local federal standards.

\section{Results and Conclusions}

Given all of the above, without any doubt, we can say that at the moment the question of development and introduction of system of internal control is one of the most urgent for many companies. We interviewed several experts in the field of accounting and auditing, which have a job for different Russian companies, about the operation of the internal control system on their companies. So based on their responses, we came to the conclusion that many companies are now concerned how to implement internal control. If they are quite clear and understandable to control objects (recall that the objects of control are the facts of economic activity of company and the every type of reporting), control technique and procedures are not clear fully (here is not so simple). In particular, the following questions arise for practicing accountants most often: who among professionals should monitor and control, what are steps and procedures of control, what methods of control may be used, where to find additional funds for the operation of the control system in the company and others.

It is important to note that over the years our country moves to the course of improving accounting. In this regard one of the main objectives of the Government is to create conditions for improving the performance of companies by forming optimal rules and regulations of accounting. For example, currently the draft of new document with recommendations on organization of the internal control system at the enterprise has on the official page of website of the Finance Ministry of Russia. This undoubtedly is a positive thing in the way of further reform and improvement of accounting system and also serves as a kind of means of practicing accountants and managers of Russian companies.

\section{References}

Henri, J.-F. Management control systems and strategy: A resource-based perspective. Accounting, Organizations and Society, 31 (6), 2006. pp: 529-558.

Needles Jr., B.E., Shigaev, A., Powers, M., Frigo, M. L. Operating characteristics of high performance companies: Strategic direction for management // Studies in Managerial and Financial Accounting, 28, 2014. pp: 25-51.

Ezeani, E., WTO post Doha: Trade deadlocks and protectionism. Journal of International Trade Law and Policy, 12 (3), 2013. pp: 272288.

Lederman, D. International trade and inclusive growth: A primer. Indian Growth and Development Review, 6 (1). 2013. pp: 88-112.

Markaryan, S.E., Snetkova, T. A., Khairullina, D. V. Administrative aspects of accounting organization. Russian experience and problems // Life Science Journal, 11(8), 2014. pp: 107-111. 
Kaspina, R. G., Khapugina, L. S., Zakirov, E. A. Interrelation of Company's Business Model Structure and Information Disclosed in Management Reporting // Life Science Journal, 11 (12), 2014. pp: 778-780.

Safiullin L.N., Fatkhiev A.M., Safiullina L.M. Projected trends and problems of education. Life Science Journal 2014; 11 (6s): $384-387$.

De la Torre, A., Feyen, E. Ize, A. Financial development: Structure and dynamics. World Bank Economic Review, 27 (3). 2013. pp: $514-$ 541.

Safiullin, L.N., Ismagilova, G.N., Gallyamova, D. Kh., Safiullin, N.Z. Consumer benefit in the competitive market // Procedia Economic and finance. 5, 2013. pp: 667-676.

Widener, S.K. An empirical analysis of the levers of control framework. Accounting, Organizations and Society, 32 (7-8). 2007. pp: 757788.

Kaspina, R.G., Khapugina, L. S., Zakirov, E. A. Employment of activity-based costing in the process of company business model generation // Life Science Journal, 11 (8), 2014. pp: 356-359.

Hagemejer, J.a., Kolasa, M. Internationalisation and economic performance of enterprises: Evidence from polish firm-level data. World Economy, 34 (1). 2011. pp: 74-100.

Panasyuk, M.V., Dzasaeva, R.D., Shaidullin, R.N., Anopchenko, T.Y. Problems of modernization of the health economics in the russian regions // World Applied Sciences Journal, 27(13), 2013, 154-158.

Isaeva, T.N., Safiullin, L.N., Bagautdinova, N.G., Shaidullin, R.N. Aspects of a multi-level study of competitive performance of objects and subjects of economic management // World Applied Sciences Journal, 27(13), 2013, 116-119.

Needles Jr., B.E., Shigaev, A., Powers, M., Frigo, M. L. Strategy and integrated financial ratio performance measures: A longitudinal multi-country study of high performance companies // Studies in Managerial and Financial Accounting, 20, 2010. pp: 211-252.

Agbejule, A., Organizational culture and performance: The role of management accounting system. Journal of Applied Accounting Research, 12 (1). 2011. pp: 74-89. 